\title{
Ophthalmic genetics: a genealogical guide to sources in England and Wales
}

\author{
Marcelle Jay
}

\begin{abstract}
Large pedigrees are fundamental to seeking new genes; they can be constructed on the basis of a family history but can frequently be enlarged considerably from public records. Genealogical sources in England and Wales consist of public records such as civil registration of births, marriages, and deaths, census returns, wills, and church records. Details are given as to their use and where they are to be found. In addition, examples are given of how archival material and pathology reports may be used to compile extensive pedigrees which can span 10 generations.
\end{abstract}

( $($ Med Genet 1995;32:946-950)

The family tree or pedigree is the cornerstone of clinical genetics and will continue to be so until well into the next century. This guide to the sources available to the family historian is designed to help clinical geneticists and researchers in expanding their family trees.

The Public Record Office (PRO) in Chancery Lane, London produces many leaflets on how to use the various archives. The Society of Genealogists has a bookshop and also a wealth of sources, including copies of parish registers, and non-members may use their facilities on payment of a search fee (see appendix 1 for addresses and details). A short list of recommended reading is given in appendix 2 .

This paper describes the sources and methods available in England and Wales to expand a pedigree, the basis of which is a detailed family history.

\section{Sources of information}

GENERAL REGISTER OFFICE

The General Register Office (GRO) is at St Catherine's House, Kingsway, London. It houses the indexes to births, marriages, and deaths in England and Wales from the beginning of civil registration which was on 1 July 1837 to the present day. Many of these data are now available on microfiche; copies are held by the Society of Genealogists and by the Church of the Latter Day Saints as well as by various libraries and some County Record Offices.

Moorfields Eye Hospital, City Road, London EC1V 2PD, UK M Jay

Received 19 June 1995 Revised version accepted fo publication 7 August 1995 name, and quarterly. It is advisable to search indexes for up to 10 years before the date given as the reported date may well be inaccurate. All entries for births after June 1911 will give the surname, the first forename in full, initials of other forenames, and the mother's maiden name. Births in the period before 1911 do not show the mother's maiden name, but do give the first two Christian names. In addition, a registration district is given with a number and a letter, followed by a volume and page number which are for reference purposes. There are maps at the GRO giving the location of registration and census districts from 1837-1851 and from 1852-1946. The registration district gives some indication as to where in England and Wales the birth took place, but there are only 10 registration districts covering the 38 counties of England and one registration district for Wales.

If it is certain that the entry sought is correct and the birth took place after 1911, one can identify the parents by inspecting the indexes for marriages. If the birth occurred before 1911 and there is no additional information, it will be necessary to obtain a birth certificate. This records date and place of birth, names, sex, name and surname of both parents, maiden name of mother, occupation of father, signature, description, and residence of informant. Some certificates show a time of day as well as the date, indicating a twin.

\section{MARRIAGES}

The indexes are ordered in the same way as those for births, but they are cross referenced only after 1911. Marriages after that date will show the surname of the person married, so both parties of a marriage will have the same reference numbers. Marriages before 1911 can only be cross checked if both surnames are known, but this is not possible if it is the woman's second marriage.

The certificates give the name of the church which then leads to the best source, the parish register. They also give the age, residence at the time of marriage, father's name and surname, and rank or profession of the father of the bride and groom, and names of the witnesses. All of these may be used to search for the entry of birth of the bride or groom. The witnesses were often related to the bride or groom and may provide a useful collateral line in a pedigree. There is a tradition that the marriage usually took place at the bride's home parish church, since no bride was prepared to travel far in her wedding finery.

On a limited budget, it is best to choose the The indexes are in alphabetical order of surmarriage certificate over the birth certificate. There may be problems, however; these arise 


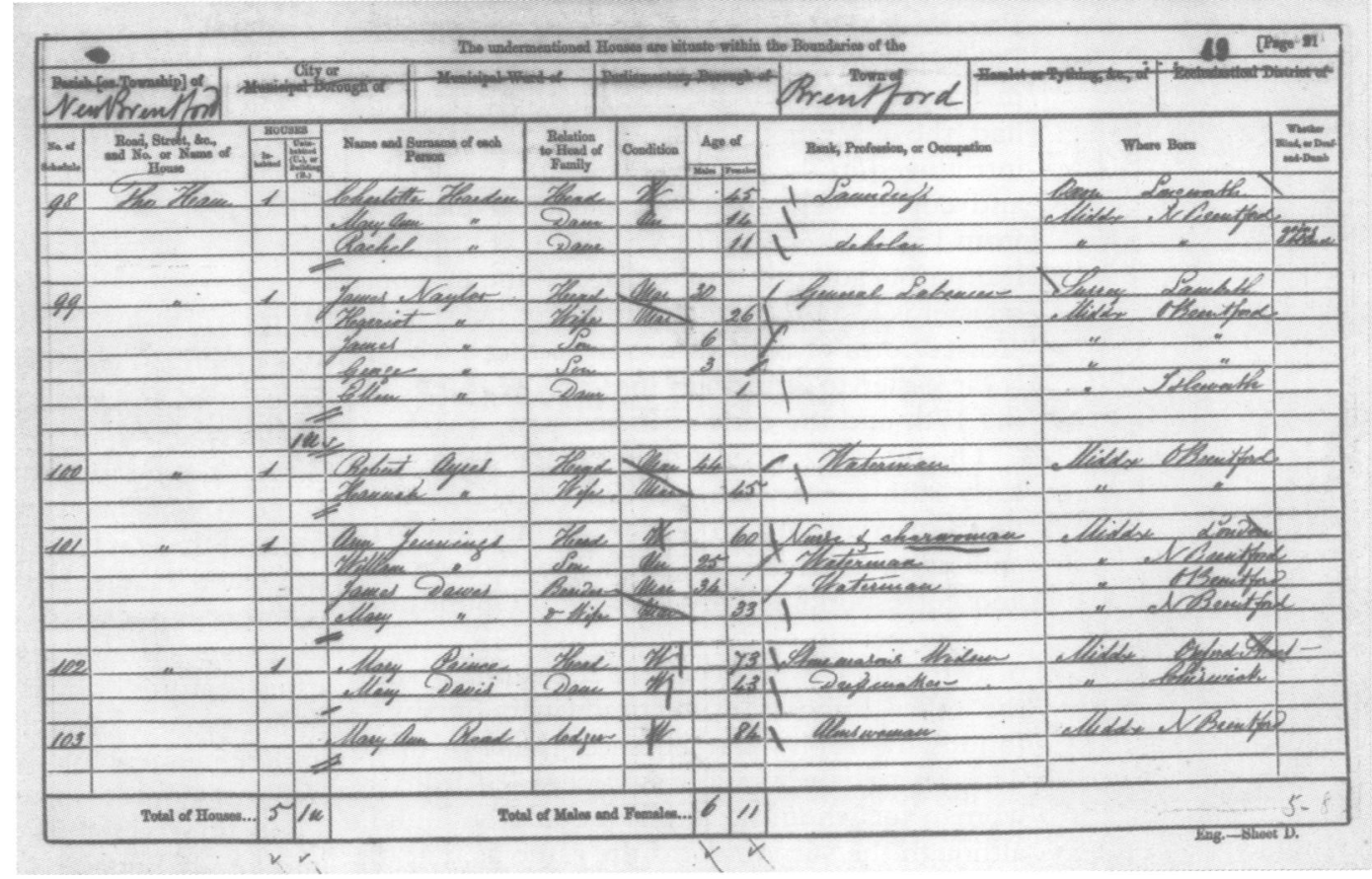

Figure 1 Entry from the 1861 census (PRO reference RG9 $777 \mathrm{f49}$ p21). The right hand column shows Rachel Harden aged 11 as "going blind". (Crown copyright, reproduced with permission of the Controller of Her Majesty's Stationery Office.)

mainly where there is illegitimacy, or if the marriage has taken place in a registry office, although this was not common practice before 1880 .

\section{DEATHS}

The indexes for deaths are ordered in the same way as those for births and marriages. Deaths occurring after 1865 show the age at death, while those occurring after March 1969 give the date of birth. The cause of death may be of relevance: "cancer of breast both removed five years, cancer of eye both removed four years, exhaustion" were given on the certificate of a woman suffering from familial malignant melanoma of the uvea. ${ }^{1}$ Death certificates in the UK are not as helpful as those in Australia which list the children of the deceased.

\section{The census}

The census in England and Wales has taken place every 10 years since 1831 . From 1841 it records by name each occupant of every dwelling in the country. After 1851, the age, sex, relationship to the head of the house, occupation, and place where born are also recorded. The manuscript returns for England and Wales 1841-1891 are on microfilm and held at the Public Record Office (PRO) in Chancery Lane, London. Microfilms for the various counties are also held in local County Record Offices and other local archives. Census returns are ordered geographically according to county and parish. The whole country was divided into enumeration districts, each comprising about 200 dwellings, and the returns for each enumeration district were the responsibility of an enumerator who had to have some knowledge of the families in his district.
The entry sought is on a single frame of microfilm, measuring $35 \mathrm{~mm}$, and the reels can be over $100 \mathrm{~m}$ long, so it is best to have an address and to make use of the many street indexes available. A useful guide on how to use the census is given in appendix 2 .

A census is shown in fig 1 , taken from the 1861 census return for Brentford, Middlesex and shows Charlotte Harden living at The Ham with her daughters Mary Ann and Rachel. Both daughters figure in a pedigree of an autosomal dominant condition, congenital hereditary corneal endothelial dystrophy. ${ }^{23}$ The last column on the right is known as the "disability" column; various terms such as "imbecile", "paralysed" were used, but the term "going blind" is extremely rare. Disabilities tended to be under-reported owing to mistrust of the authorities, but their use in the census attracted the attention of Charles Darwin. His own children were the product of a cousin marriage with a member of the Wedgwood family. Darwin wanted to know whether the census could be used to relate disabilities to cousin marriages, and asked his friend and MP, John Lubbock, to bring up the matter in Parliament. The proposed amendment to the Census Bill of 1870 was defeated by a margin of two to one. ${ }^{4}$ The topic of cousin marriage was afterwards studied by Darwin's son George Howard. ${ }^{5}$

The census is valuable as a source of local surnames, many of which are regional. Even a fairly common surname can be followed through the censuses from a village and traced back to a single founder. This, of course, is most helpful in autosomal dominant inheritance, but it is less helpful for $\mathrm{X}$ linked transmission which relies on the maternal maiden name; it is then necessary to find the relevant marriage either from civil registration or from parish registers if the period is before 1837 . 


\section{Parish registers}

Parish registers are church records of baptisms, marriages, and burials, and in the past also had the accounts of the parish. They were introduced in the time of Elizabeth $I$ in 1538, and copies were made for the local bishops from 1597. These copies are known as bishop's transcripts and can be invaluable if the original register is lost or illegible. From 1813, a standardised form of register was introduced which is far easier to read than the early registers of the 17 th and the early 18 th century.

The practice of baptism in the late 18th and early 19 th century was not universal. One can find a marriage of a 20 year old woman in 1831 and fail to find her baptism, but both marriage and corresponding baptism may be found for another person of the same surname. A study of two different branches, one Australian and the other English, of a family with Sorsby's fundus dystrophy may be an example of this. The Australian branch was descended from a woman for whom no baptism could be found although the surname was the same as that of the ancestor of the English branch. ${ }^{6}$

Before 1754, only the names of the bride and groom were given in the entry of their marriage. Later the names of witnesses were added, but the names and occupation of the father of the bride and groom were not recorded until the introduction of the new type of registers in 1837.

Early entries of burials were very brief with only the name of the deceased and the date of burial, with some notable exceptions. An entry in the register for Welkenraedt, a province of Liège in Belgium records the death in 1793 of Anne-Marie Vercken, born in 1731, who died after 10 years of incessant tremors of her body (per decem annos toto corpore indesinenter

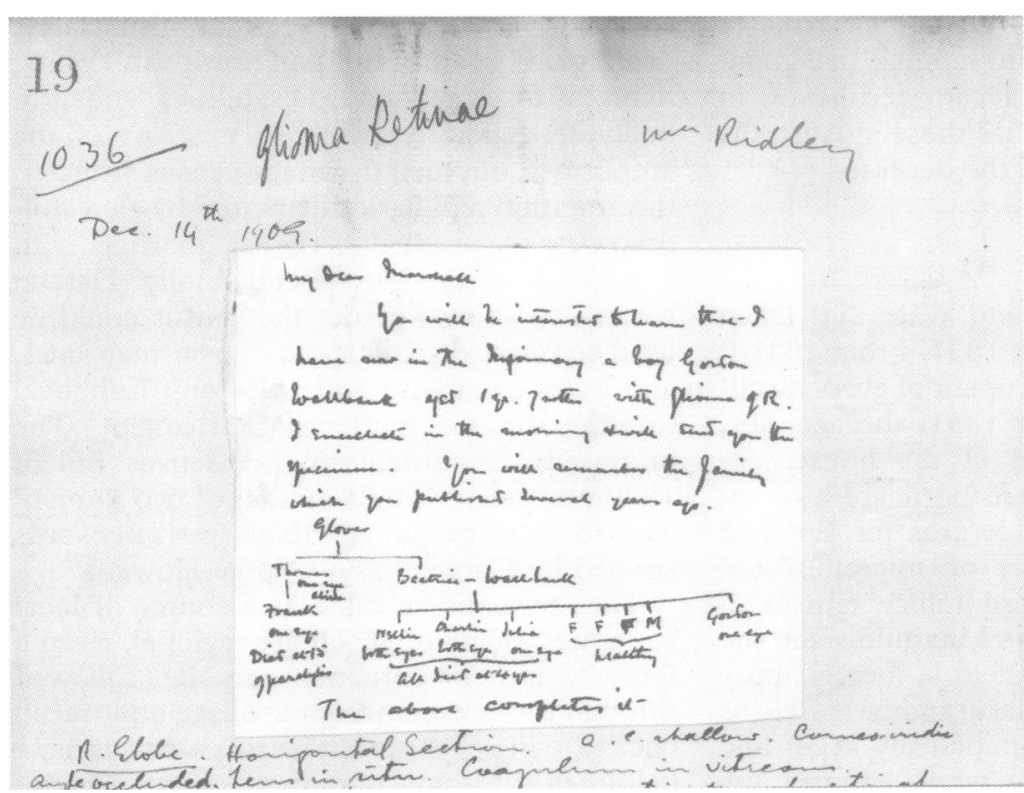

Figure 2 Entry from the registers of the Department of Pathology of the Institute of Ophthalmology. The letter from Mr Ridley reads: "My dear Marshall, You will be interested to learn this -I have now in the Infirmary a boy Gordon Wallbank aged 1 yr. 7 months with glioma of $R$. I enucleate in the morning and will send you the specimen. You will remember the family which you published several years ago." Beneath the pedigree are the words: "The above completes it". tremula). This woman was the ancestor of a family with Huntington's chorea. ${ }^{\text {? }}$

The parish registers in use at the present time are held by the church, but most of the old registers are held in local County Record Offices.

\section{Wills}

Wills, which were originally proven by the Church of England, provide a further source of information. It is known that of wills left during the period from 1500 to 1800 , on average 10 persons were mentioned in each and most of these were relatives of the deceased. A will dated 7 April 1785 was used to identify the different branches of a family with autosomal dominant retinitis pigmentosa with some unusual features, which has given rise to several publications ${ }^{8-10}$ as well as a DNA linkage study and refinement of the locus. ${ }^{1112}$ Other posthumous sources are inscriptions on graves, some transcribed by family history societies, and family Bibles.

\section{The International Genealogical Index}

The Church of Jesus Christ of Latter Day Saints, also known as the Mormon Church, has compiled a computerised index of baptisms and marriages which is updated regularly and this index is known as the IGI (International Genealogical Index). The index is ordered by county, and the surnames are in alphabetical order with baptisms and marriages in chronological order. It is useful for the period before 1837 and can give some idea of the distribution of a surname. The IGI can be found at local County Record Offices and also at some large libraries.

\section{Other sources}

\section{PATHOLOGY}

Pathology departments have a disease index and named records. The earliest surviving reports of ocular pathology performed at the Royal London Ophthalmic Hospital date from 1860, and until just before the First World War, pathology was performed by clinical ophthalmologists with an interest in the subject. A pedigree of retinoblastoma was found in a report dated 14 December 1909 (fig 2). The grandfather had one eye enucleated for retinoblastoma at the age of 5 months by William Bowman in 1858 . He survived to have a grandson with retinoblastoma who died at the age of 15 of "paralysis". His daughter BW had eight children, four of whom were affected with retinoblastoma, three of whom died in infancy, although she herself was unaffected.

Another family with retinoblastoma, identifiable from pathology reports, has been published for the association with other primary malignant tumours, ${ }^{13}$ for an immunogenetic study, ${ }^{14}$ to illustrate the accuracy of detection of the gene by esterase D linkage, ${ }^{15}$ and as family RB56 in a study of DNA polymorphisms within the retinoblastoma gene. ${ }^{16}$ 


\section{ARCHIVES}

The best known archive in the history of ophthalmology is that of the private papers of Edward Nettleship (1845-1913), the founder of ophthalmic genetics. After his death and at the suggestion of William Bateson, the great statistician and geneticist who knew him well, Mrs Nettleship was approached and she sent all his private papers to $\mathrm{Mr}$ (later Sir) John Parsons. In a letter dated 16 July 1916 she wrote:

"I do hope that the number of papers may not frighten you-but I thought it best to send everything - a great deal must, I know, be destroyed-please do this as I suppose only a few are necessary to show the method of work $\&$ that seems to be what $\mathrm{Mr}$ Bateson means-". The last letter is dated 20 July 1916 in which Mrs Nettleship wrote:

"Indeed I quite agree with you as to the Moorfields library being the best place for the M.S.S. and I know that my husband would like it best."

The Nettleship papers were ultimately given to Sir Steward Duke-Elder for the library of the new Institute of Ophthalmology which is now in the Ashton Building in Bath Street, on a site directly behind Moorfields Eye Hospital.

The papers are a collection of working pedigrees in all their different stages, with pencilled notes, and all the correspondence relevant to each pedigree. They include a pedigree of autosomal dominant cataract published in $1909,{ }^{17}$ which is one of the first examples of autosomal linkage, that is, of congenital cataract and the Duffy blood group locus. ${ }^{18}$

\section{PUBLISHED PEDIGREES}

Published pedigrees may appear in a thesis or in journals. A thesis is a publication obtainable from the university granting the degree, and often a paper based on the thesis appears some time later. ${ }^{1920}$ The thesis, however, has more detailed family data, such as first names and initial of surname.

Pedigrees published before 1950 often had appendices with sufficient detail, including one surname, to enable a researcher to identify every person and their descendants from public records; the Bowman Lecture of 1935 by Charles Usher is one example, ${ }^{21}$ while Arnold Sorsby $^{2223}$ and Burn ${ }^{24}$ are more recent ones.

\section{FAMILY HISTORY SOURCES}

It is apparent that the tracing of ancestry or descent depends on finding sources. The situation in Scotland ${ }^{25}$ and in Wales ${ }^{26}$ is somewhat different, while Irish ancestry is a very specialised subject. Almost every county of England and Wales has its own family history society which publishes a quarterly journal with members' interests and many of these journals have a worldwide readership, particularly in the USA. These societies hold local marriage indexes and copies of local census returns, and are most helpful.

It should be possible to trace a family back through eight or nine generations, but it is exceptional to be able to go further back than the mid 18th century. For a number of reasons, baptismal records in England and Wales cannot compare with those to be found in Scandinavia or elsewhere in Northern Europe.

\section{THE PRESENT DAY}

The tracing of descent can be more difficult than that of ancestry as people moved away from their origins. In the UK, the National Health Service and the resources of the $\mathrm{DOH}$ mean that it is usually possible to trace people through their General Practitioners. It is possible to do so by using local telephone books, or by access to a national database which corresponds to the telephone directory of the whole country.

The family tree itself can be stored on any one of several computer programs available to genealogists and there is a quarterly periodical devoted to the topic (appendix 2). Most of the work described here has been to generate pedigrees for use in linkage analysis, and members of families are inevitably interested in obtaining a copy of the family tree. The family tree itself is public domain, but the pedigrees used in linkage contain confidential information. It is worth considering a simple program to generate the family tree and thereby keep the goodwill of the family, and because of the time involved in entering data, the simpler the program the better.

\section{Comment}

It is hoped that this guide to genealogical sources in England and Wales will inspire all those who are involved in the taking and recording of family histories. It is hoped that they will consider the undeniable advantages of diagnostic registers in providing the source material of genetics, the patients and their families.

I am grateful for the support of the British Retinitis Pigmentosa Society, the National Retinitis Pigmentosa Foundation, and Cancer Research Campaign for funding this research. In particular, I would like to thank Dr Sarah Bundey for her encouragement. I would also like to thank all my colleagues
in clinical ophthalmology and in molecular genetics for their in clinical ophthalmology and in molecular genetics for their
interest. I also thank Professor Alan Bird for his constant interest. I also thank Professor Alan Bird for his constant guidance and, in particular, for drawing my attention to the study of George Darwin. I also acknowledge with gratitude all
the help I have received from archivists and family historians.

Appendix 1. Some useful addresses

General Register Office, St Catherine's House, 10 Kingsway, London WC2B 6JP.

Greater London Record Office, 40 Northampton Road, London EC1R OHB, 0171-332 3820 .

Guildhall Library, Aldermanbury, London EC2P 2E

Public Record Office, Chancery Lane, London WC2 1LR.

Society of Genealogists, 14 Charterhouse Buildings, Goswell Road, London EC1M 7BA, 0171-251 8799. Search fee for non-members: ${ }^{3} .00$ an hour, 57.50 for 4 hours, 110.00 for non-members: $£ 3.00$ an hour, $£ 7.50$ for 4 hours, $£ 10.00$ for day. Closed Mondays.

Appendix 2. Recommended reading

Record offices: how to find them. Jeremy Gibson and Pamela Record offices: how to find them. Jeremy Gibson and Pamela of Family History Societies, C/o Benson Room, Birmingham of Family History Societies, C/o Benson Room, Birmingham and Midland institute, Margaret Street, Birmingham B3 3BS. This booklet is one of a series of guides for genealogists, family and local historians. It has street maps, includes car parks, bus, and railway stations, and addresses of the County Record Offices of England and Wales.

The family tree detective. Colin D Rogers, Manchester University Press. An excellent basic manual. 2nd ed. 1986, price $£ 8.50$. 
Computers in genealogy. Quarterly periodical available from Society of Genealogists.

The censuses 1841-1891 use and interpretation. Eve McLaughlin. $£ 1.50$, obtainable either at the Public Record Office bookshop or from the author, Varneys, Rudds Lane, Haddenham, Aylesbury, Bucks HP17 8JP. The McLaughlin guides cover series of topics and provide an excellent introduction to the subject. This particular volume is easy to use and very use friendly; it even describes how to thread the microfilm on to the viewer. Other titles of interest in this series include Interviewing elderly relatives and Illegitimacy. Making sense of the Census. Edward Higgs. Public Record Office Handbooks No 23, London: HMSO, 1989. Obtainable from the Public Record Office bookshop, or HMSO Publications Centre, PO Box 276 London SW8 5DT. Price 9.95 . This is to be recommended as a more detailed reference book which is also very readable. The Oxford guide to family history. Une Oxford guide to family history. David Hey. 1993. Oxford niversity Press. Price $£ 1$. book, which covers every aspect of family history. It is essentially a reference book which gives a fascinating insight into the methods used by genealogists. Geneticists will find

interest, particularly in the chapter on family names.
Phillimore atlas and index of parish registers. Cecil HumpheryPhillimore atlas and index of parish registers. Cecil HumpherySmith. Phillimore Co Ltd. New edition obtainable from July 1995 , price $£ 50$. Obtainable at all good bookshops and from the publishers at Shopwyke Hall Barn, Chichester, W Sussex
PO20 6BG. This is the "McKusick" of genealogy and includes county maps with their divisions into parishes. The parishes are listed according to county, and locations of each are tabulated including county record offices, copies at the Society of Genealogists, copies elsewhere, local marriage indexes, nonconformist records at the PRO, and more. The new edition will include Scotland.

1 Jay M, McCartney ACE. Familial malignant melanoma of the uvea and p53: a Victorian detective story. Surv Ophthe uvea and p53: a Victor

2 Pearce WG, Tripathi RC, Morgan G. Congenital endothelial corneal dystrophy. Br f Ophthalmol 1969;53:577-91.

3 Kirkness CM, McCartney A, Rice NSC, Garner A, Steel ADMcG. Congenital hereditary corneal oedema of Maumenee: its clinical features, management and pathology. Br f Ophthalmol 1987;71:130-44.

4 Desmond A, Moore J. Darwin. London: Michael Joseph 1991:575

5 Darwin GH. Marriages between first cousins in England and their effects. $\mathcal{F}$ Statistical Soc 1875;38:153-82.

6 Kalmus H, Seedburgh D. Probable common origin of a hereditary fundus dystrophy (Sorsby's familial pseudoinflammatory macular dystrophy) in an English and Australian family. 7 Med Genet 1976;13:271-6.

7 Husquinet $\mathrm{H}$. Chorée de Huntington. L'experience liégeoise. F Genet Hum 1985;33:107-18.
8 Jay M, Bird AC, Moore AN, Jay B. Nine generations of a family with autosomal dominant retinitis pigmentosa and evidence of variable expressivity from census records. $\mathcal{f}$ Med Genet 1992;29:906-10

9 Moore AN, Fitzke F, Jay $M$, et al. Autosomal dominant retinitis pigmentosa with apparent incomplete penetrance: a clinical, electrophysiological, psychophysical, and molecular genetic study. Br f Ophthalmol 1993;77:473-9.

$10 \mathrm{Kim}$ RY, Fitzke FW, Moore AT, et al. Autosomal dominant retinitis pigmentosa mapping to chromosome $7 \mathrm{p}$ exhibits variable expression. $\mathrm{Br} \mathcal{f}$ Ophthalmol 1995;79:23-7.

11 Inglehearn CF, Carter SA, Keen TJ, et al. A new locus for autosomal dominant retinitis pigmentosa on chromosome $7 \mathrm{p}$. Nature Genet 1993;4:51-3.

12 Inglehearn CF, Keen JT, Al-Maghtheh $\mathrm{M}$, et al. Further refinement of the location for autosomal dominant retinitis pigmentosa on chromosome $7 \mathrm{p}$ (RP9). Am $\mathcal{f}$ Hum Genet 1994;54:675-80.

13 Aherne G. Retinoblastoma associated with other primary malignant tumours. Trans Ophthalmol Soc UK 1974;94: 938-44.

14 Jones AL. Immunogenetics of retinoblastoma. Trans Ophthalmol Soc UK 1974;94:945-52.

15 Halloran S, Boughman JA, Dryja TP, et al. Accuracy of detection of the retinoblastoma gene by esterase $\mathrm{D}$ linkage. Arch Ophthalmol 1985;103:1329-31.

16 Wiggs J, Nordenskjöld M, Yandell D, et al. Prediction of the risk of hereditary retinoblastoma, using DNA polymorphisms within the retinoblastoma gene. $N$ Engl f Med 1988;318:151-7.

17 Nettleship E. Seven new pedigrees of hereditary cataract. Trans Ophthalmol Soc UK 1909;29:188-210.

18 Renwick JH, Lawler SD. Probable linkage between a congenital cataract and the Duffy blood group locus. Ann Hum Genet 1993;27:670-84.

19 Waheed I. Progressive bifocal chorio-retinal atrophy. MD thesis, University of St Andrews, 1964.

20 Douglas AA, Waheed I, Wyse CT. Progressive bifocal chorio-retinal atrophy: a rare familial disease of the eyes. chorio-retinal atrophy: a rare familial

21 Usher CH. The Bowman Lecture. On a few hereditary eye affections. Trans Ophthalmol Soc UK 1935;55:164-245.

22 Sorsby A, Franceschetti A, Joseph R, Davey JB. Choroideremia. Br f Ophthalmol 1952;36:547-81.

23 Sorsby A, Mason MEJ, Gardener N. A fundus dystrophy with unusual features. $B r \mathcal{F}$ Ophthalmol 1949;33:67-97.

24 Burn RA. Further cases of a fundus dystrophy with unusual features. Br f Ophthalmol 1950;34:393-403.

25 Collyer S, DeMey R. Public records and recognition of genetic disease in Scotland. Clin Genet 1987;31:125-31.

26 Moore P. Parish registers and sources for genealogical studies in Wales. In: Harper PS, Sunderland E, eds. Genetic and population studies in Wales. Cardiff: University of Wales Press, 1986:251-69. 